\title{
MANAJEMEN KEPALA SEKOLAH DALAM MEWUJUDKAN SEKOLAH ADIWIYATA \\ (STUDI KASUS DI SD NEGERI 02 TANAH PAK LAMBIK KOTA PADANG PANJANG)
}

\author{
Basri \\ Operator Bidang Pendidikan Diniyah dan Pondok Pesantren \\ Kemenag Kota Padang Panjang-Sumatera Barat \\ e-mail: pendipontrenpdgpjg@gmail.com
}

\begin{abstract}
$+20$
Abstract: This research to describe the management of the principal in realizing the adiwiyata school in SD Negeri 02 Tanah Pak Lambik Padang Panjang City. This study is qualitative. Data collection is done through observation, interview and documentation study. The results showed that in realizing the adiwiyata program at SD Negeri 02 Tanah Pak Lambik, various management functions were applied by the principal. Starting from the planning, organizing, implementation and control performed by the principal, then with the hard work of the principal and all related elements can be realized adiwiyata program di SD Negeri 02 Tanah Pak Lambik.
\end{abstract}

Keywords: Manajemen, Kepala Sekolah, Adiwiyata, SD Negeri 02 Tanah Pak Lambik

\section{PENDAHULUAN}

Memperlakukan alam lingkungan untuk pemanfataan sumber daya alamnya dengan cara-cara yang adil dengan tetap mengedepankan prinsip melindungi tanpa berbuat kerusakan. Di samping itu manusia sebagai khalifah (sebagai pemimpin di muka bumi) memiliki tugas dan tanggung jawab mengurusi bumi dalam artian menjaga kestabilan alam lingkungan dengan mengedepankan kemakmuran. Perintah untuk tidak berbuat kerusakan di muka bumi ini firman Allah SWT dalam alQur'an Surat al-A'raf, yang artinya "Dan janganlah kamu membuat kerusakan di muka bumi, sesudah (Allah) memperbaikinya dan Berdoalah kepada-Nya dengan rasa takut (tidak akan diterima) dan harapan (akan dikabulkan). Sesungguhnya rahmat Allah Amat dekat kepada orang-orangyang berbuat baik. (QS. Al-A'raf: 56).

Dalam Undang-Undang Perlindungan dan Pengelolaan Lingkungan Hidup Nomor 32 Tahun 2009 dijelaskan bahwa lingkungan hidup adalah kesatuan ruang dengan semua benda, daya, keadaan, dan makhluk hidup, termasuk manusia dan perilakunya, yang mempengaruhi alam itu sendiri, kelangsungan perikehidupan, dan kesejahteraan manusia serta makhluk hidup lain.Permasalahan lingkungan hidup tidak 
dapat dipisahkan secara teknis semata, namun yang lebih penting adalah pemecahan yang dapat mengubah mental serta kesadaraan akan pengelolaan lingkungan. Untuk mengatasi dampak kerusakan lingkungan hidup diperlukan suatu perubahan sikap dan perilaku pada masyarakat serta perbaikan moral melalui pendidikan.

Pendidikan sangat mempengaruhi perkembangan fisik, daya jiwa (akal, rasa dan kehendak), sosial dan moralitas manusia serta merupakan alat terpenting untuk menjaga diri dan memelihara nilai-nilai positif. Tentunya dengan pengaruh yang ditimbulkan pendidikan ini memberikan dampak pada bertambahnya pengetahuan dan keterampilan serta akan menolong dalam pembentukan sikap yang positif. Pendidikan memberikan peluang kepada masyarakat untuk melakukan suatu tindakan atau pengalaman yang mempengaruhi pertumbuhan atau perkembangan jiwa, watak, atau kemampuan fisik mereka melalui lembaga-lembaga pendidikan yang dengan sengaja mentransformasikan warisan budayanya, yaitu pengetahuan, nilai-nilai dan keterampilan-keterampilan dari generasi ke generasi. Semua pihak diharapkan dapat turut serta melakukan penyelamatan dan pelestarian lingkungan hidup dengan mengembangkan sikap, bentuk-bentuk perilaku, kemampuan sosial dan kemampuan individu yang mencintai lingkungan.

Pendidikan lingkungan hidup di sekolah merupakan salah satu dari penerapan pendidikan karakter. Pendidikan karakter dan pendidikan lingkungan hidup menanamkan nilai-nilai karakter kepada warga sekolah yang meliputi pengetahuan (kognitif), kesadaran atau kemauan (afektif), dan tindakan (psikomotor) untuk melaksanakan nilainilai tersebut. Sebuah lembaga pendidikan akan dapat mewujudkan sekolah adiwiyata apabila perencanaanya tertata dengan rapi. Sebelum membuat perencanaan diharapkan untuk memperhatikan kondisi dan situasi lingkungan sekolah, baik dari segi sarana sampai kepada kebutuhan dana yang memadai. Hal tersebut sangatlah urgen untuk dijadikan pertimbagan dalam mengambil sebuah keputusan.

Selanjutnya fungsi manajemen yang terakhir adalah pengawasan, agar pekerjaan dalam mewujudkan sekolah adiwiyata di SD Negeri 02 Tanah Pak Lambik berjalan sesuai dengan visi, misi, aturan dan program kerja maka dibutuhkan pengontrolan. Baik dalam bentuk supervisi, pengawasan, inspeksi hingga audit. Kata-kata tersebut memang memiliki makna yang berbeda, tapi yang terpenting adalah bagaimana sejak dini dapat diketahui penyimpangan-penyimpangan yang terjadi. Baik dalam tahap perencanaan, pelaksanaan maupun pengorganisasian. Sehingga dengan hal tersebut dapat segera dilakukan koreksi, antisipasi dan penyesuaian-penyesuaian sesuai dengan situasi, kondisi dan perkembangan zaman. Pengawasan salah satu unsur manajemen yang sangat urgen, tanpa adanya pengawasan maka tidak aka nada follow up dari sebuah 
program sehingga program tersebut tidak ada perkembangannya.

Tujuan program adiwiyata di sekolah Kepala SD Negeri 02 Tanah Pak Lambik adalah untuk mewujudkan warga sekolah yang bertanggung jawab dalam upaya perlindungan dan pengelolahan lingkungan hidup melalui tata kelola sekolah yang baik untuk mendukung pembangunan yang berkelanjutan. Banyak prestasi yang telah di raih oleh SD Negeri 02 Tanah Pak Lambik, diantaranya juara 1 lomba rungan UKS terbersih di tingkat Kota Padang Panjang dan meraih adiwiyata di Tingkat Provinsi.

Dengan melaksanakan program Adiwiyata akan menciptakan warga sekolah, khususnya peserta didik yang peduli dan berbudaya lingkungan, sekaligus mendukung dan mewujudkan sumberdaya manusia yang memiliki karakter bangsa terhadap perkembangan ekonomi, sosial, dan lingkungannya dalam mencapai pembangunan berkelanjutan di daerah.

\section{LANDASAN TEORI}

\section{Manajemen}

Kata manajemen berasal dari bahasa latin, yaitu kata manus dan agree yang berarti malakukan. Kata-kata itu digabung menjadi kata kerja managere yang artinya menangani. Managere diterjemahkan dalam bahasa Inggris dalam bentuk kata kerja to manage, dengan kata benda dengan management, dan manager untuk orang yang melakukan kegiatan Manajemen. Akhirnya Manajemen diterjemahkan dalam bahasa Indonesia menjadi manajemen atau pengelolaan. (Husaini Usman: 2006)

Manajemen adalah ilmu dan seni yang mengatur proses pemanfaatan sumberdaya manusia dan sumber sumber lainnya secara efektif dan efisien untuk mencapai suatu tujuan tertentu. Sedangkan menurut Malayu dalam mendefinisikan manajemen merupakan suatu proses yang terdiri dari tindakantindakan perencanaan, pengorganisasian, menggerakkan dan mengendalikan, yang dilakukan untuk menentukan serta mencapai sasaran yang telah ditentukan melalui pemanfaatan sumber daya manusia dan sumber daya lainnya (Malayu, 1990:3).

Sedangkan menurut Pidarta, manajemen ialahproses mengintegrasikan sumbersumber yang tidak berhubungan menjadi sistem total untuk menyelesaikan suatu tujuan, yang dimaksud sumber disini ialah mencakup orang orang, alat-alat media, bahan-bahan, uang dan sarana. Semuanya diarahkan dan dikoordinasi agar terpusat dalam rangka menyelesaikan tujuan (Pidarta: 1988: 3). Gaffar mengemukakan bahwa manajemen pendidikan mengandung arti sebagai suatu proses kerja sama yang sistematik, sistemik, dan komprehensif dalam rangka mewujudkan tujuan pendidikan nasional. Manajemen pendidikan juga dapat diartikan sebagai segala sesuatu yang berkenaan dengan pengelolaan proses 
pendidikan untuk mencapai tujuan yang telah ditetapkan, baik tujuan jangka pendek, menengah, maupun tujuan jangka panjang (Pidarta, 1988: 4).

Manajemen pendidikan adalah sebagai seni dan ilmu mengelola sumber daya pendidikan untuk mewujudkan suasana belajar dan proses pembelajaran agar peserta didik secara aktif mengembangkan potensi dirinya untuk memiliki kekuatan spiritual keagamaan, pengendalian diri, kepribadian, kecerdasan, akhlak mulia, serta keterampilan yang diperlukan dirinya, masyarakat bangsa dan Negara. Dapat juga diartikan manajemen pendidikan juga merupakan rangkaian kegiatan bersama atau keseluruhan proses pengendalian usaha atas kerjasama. Sekelompok orang dalam mencapai tujuan pendidikan yang telah ditetapkan secara berencana dan sistematis, yang diselenggarakan pada suatu lingkungan tertentu manajemen pendidikan pada hakekatnya menyangkut tujuan pendidikan, manusia yang melakukan kerjasama, proses sistemik dan sistematik,serta sumber-sumber yang didayagunakan.

Sebagai suatu tujuan yang telah ditetapkan tentunya manajemen mempunyai suatu langkah langkan yang sistemik dan sistematik dalam mencapai suatu tujuan yang ingin dicapai. Dalam arti yang lebih luas manajemen juga bisa disebut sebagai pengelolaan sumber-sumber guna mencapai suatu tujuan yang telah ditetapkan, karenanya manajemen ini memegang peranan yang sangat urgen dalam dunia pendidikan.
Tujuan manajemen pendidikan erat sekali dengan tujuan pendidikan secara umum, karena manajemen pendidikan pada hakekatnya merupakan alat untuk mencapai tujuan pendidikan secara optimal. Apabila dikaitkan dengan pengertian manajemen pendidikan pada hakekatnya merupakan alat mencapai tujuan. Adapun tujuan pendidikan nasional yaitu untuk mengembangkannya potensi peserta didik agar menjadi manusia yang beriman dan bertaqwa kepada tuhan yang maha esa, berakhlak mulia, sehat, berilmu, cakap, kreatif, mandiri, dan menjadi warga Negara yang demokratis serta bertanggung jawab. Dalam UU Sisdiknas No. 20 Tahun 2003, tujuan pokok memperlajari manajemen pendidikan adalah untuk memperolehcara,tehnik, metode yang sebaik-baiknya dilakukan, sehingga sumber-sumber. Yang sangat terbatas seperti tenaga, dana, fasilitas, material maupun sepiritual guna mencapai tujuan pendidikan secara efektif dan efisien. Dalam proses manajemen terlibat fungsifungsi pokok yang disebut seorang manajer/ pemimpin, yaitu perencanaan (planning), perngorganisasia (organizing), penggerakan (actualiting), dan pengawawan (controlling). (Fattah, 1996: 1).

\section{Kepala Sekolah}

Secara etimologi menurut kamus besar bahasa Indonesia, Kepala Sekolah adalah orang atau guru yang memimpin suatu Sekolah. Dengan demikian Kepala Sekolah 
merupakan pihak yang ditunjuk untuk memimpin suatu lembaga pendidikan.

Sedangkan secara terminologi, Wahjosumidjo mengemukakan pengertian Kepala Sekolah adalah sebagai seorang tenaga profesional guru yang diberi tugas untuk memimpin suatu sekolah di mana diselenggarakan proses belajar mengajar "atau" tempat dimana terjadi interaksi antara guru yang memberi pelajaran dan murid yang menerima pelajaran (Wahjosumidjo, 1999: 83).

Seorang Kepala Sekolah yang memimpin sebuah lembaga pendidikan bertugas memenuhi kebutuhan kelompok yang dipimpinnya, yakni lembaga pendidikan. Dalam hal ini Purwanto menyatakan bahwa "Tugas seorang pemimpin lembaga pendidikan, kecuali harus memenuhi kebutuhan kelompok juga harus dapat mempengaruhi kelompok sedemikian rupa sehingga apa yang dirasakan sebagai kebutuhan benar-benar bersifat realistis, yaitu sesuai dengan kenyataan, idam-idam mau kelompok yang buruk-buruk atau hanya khayalan belaka harus dirombak oleh pemimpin ke dalam kehendak yang realistis" (Purwanto, 1998: 62).

Berdasarkan tugas praktis yang diemban oleh Kepala Sekolah tersebut tergambar bahwa seorang Kepala Sekolah sebagai pemimpin lembaga pendidikan harus dapat mengembangkan dan menyalurkan kebebasan berfikir seluruh guru dan perangkat Sekolah yang ada sehingga akan tercipta suasana kerja yang efektif dan efisien. Selain itu Kepala Sekolah juga harus dapat mendorong terjadinya persamaan terdapat dengan sikap saling menghargai dalam menyelesaikan tugas-tugas yang berkaitan dengan saling menghormati dalam menyelesaikan tugas-tugas yang berkaitan dengan kemajuan lembaga pendidikan.

Sementara itu Soetopo dan Soemanto menyatakan pula bahwa tugas Kepala Sekolah sebagai pendidikan terbagi atas dua bagian yaitu pertama tugas yang bertalian dengan tujuan yang hendak dicapai, kedua tugas yang bertalian dengan menciptaan suasana pekerjaan yang sehat. Pendapat ini juga berkaitan dengan tugas Kepala Sekolah dalam menangani masalah-masalah teknis yang ada di Sekolah dan juga membangun kerja tim yang baik di Sekolah yang dipimpinnya.

Dari ketiga pendapat yang dikemukakan di atas, terlihat adanya persamaan pendapat antara keduanya tentang tugas Kepala Sekolah, yakni sama-sama memberikan penekanan pada penyesuaian manajerial persoalan yang dihadapi dalam lembaga pendidikan. Persoalan manajerial ini di antaranya adalah kemampuan yang harus ditonjolkan Kepala Sekolah dalam kemampuan untuk menyelesaikan masalah jika terjadi perbedaan pendapat ataupun terjadinya konflik dalam lembaga pendidikan.

Kepala Sekolah adalah seorangyang sangat bertanggung jawab dalam meningkatkan mutu lembaga yang dipimpinnya. Sebagai 
orang yang sangat bertanggung- jawab dalam perkembangan maju atau mundurnya lembaga yang dia pimpin, maka seorang pemimpin harus memiliki sifat-sifat yang dapat diterima dan disenangi oleh orang yang dipimpinnya. Kalau seorang Kepala Sekolah itu sudah disenangi oleh semua warga atau seluruh komponen yang terkait di Sekolah tersebut. Sehubungan dengan yang demikian maka Kepala Sekolah perlu memperhatikan beberapa hal dalam mengelola pendidikan untuk peningkatan dan pengembangan Sekolah yaitu sifatsifat yang dapat menunjang keberhasilan dalam mempengaruhi guru-guru bawahan lainnya. Ada beberapa sifat yang diperlukan dalam kepemimpinan pendidikan, yaitu: (1) rendah hati dan sederhana, (2) bersifat suka menolong, (3) sabar dan memiliki kestabilan emosi, (4) percaya kepada diri sendiri, (5) Jujur, adil dan dapat dipercaya, (6) keahlian dalam jabatan (Soetopo dan Soemanto, 1988: 55).

Di samping mengetahui dan menguasai tugas dan fungsi Kepala Sekolah, Kepala Sekolah harus dilengkapi dengan kemampuan dalam berbagai keterampilan, diantaranya adalah keterampilan pengelolaan pendidikan secara profesional. Ada beberapa kemampuan dan keahlian yang harus dimiliki oleh seorang Kepala Sekolah, yaitu: (Soetopo dan Soemanto, 1988: 392-393).

1. Kepala Sekolah harus dapat berfungsi sebagai seorang pendidik, yang mampu mengajar, memberikan peragaan, melaksanakan pertemuan, dan memberi bimbingan.

2. Kepala Sekolah harus menjadi mahkota dari berbagai macam teknik mengajar, seperti audio aids, roli playing, pertanyaan dan merencanakan pengajaran.

3. Kepala Sekolah harus mampu menampilkan analisis tinggi untuk mengumpulkan, mencatat dan menguraikan tugas pekerjaan, dan elemenelemen jabatan/kedudukan, mampu memamfaatkan data untuk menentukan proses belajar mengajar, menerjemahkan persyaratan ke dalam sasaran pendidikan dan merencanakan satu sistem pengajaran yang akan mampu mencapai sasaran.

4. Kepala Sekolah harus mampu mengembangkan silabus rangkaian mata pelajaran (caurce) dan program-program pengajaran, menyusun lesson plan dan dokumen pengajaran yang lain, menyusun test keberhasilan dan merencanakan peralatan pendidikan.

5. Kepala Sekolah harus mampu merencanakan dan melaksanakan penelitian dalam pendidikan dan mempergunakan temuan riset itu untuk mempergunakan program pendidikan.

6. Kepala Sekolah harus mampu mengadakan supervisi dan evaluasi pengajaran, fasilitas, kelengkapan dan materi pengajaran.

7. Kepala Sekolah mengetahui apa yang terjadi di luar Sekolah yang berhubungan dengan paket dan pelayanan pendidkan, harus mampu merumuskan dan 
melaksanakan program pengembangan diri secara berkelanjutan dan sistematik.

8. Kepala Sekolah harus menjadi seorang pemimpin yang baik dan seorang komunikator yang efektif.

Dengan demikian Kepala Sekolah harus memiliki kepemimpinan yang profesional dalam menjalankan segala aktivitas dalam berbagai bidang terutama bidang pendidikan, dan sebagai tolak ukur untuk mencapai keberhasilan Sekolah terutama anak didik dalam mencapai pendidikan ke jenjang yang lebih tinggi.

\section{Adiwiyata}

Adiwiyata mempunyai pengertian atau makna sebagai tempat yang baik dan ideal dimana dapat diperoleh segala ilmu pengetahuan dan berbagai norma serta etika yang dapat menjadi dasar manusia menuju terciptanya kesejahteraan hidup kita dan menuju kepada cita-cita pembangunan berkelanjutan. Tujuan program Adiwiyata adalah mewujudkan warga sekolah yang bertanggung jawab dalam upaya perlindungan dan pengelolaan lingkungan hidup melalui tata kelola sekolah yang baik untuk mendukung pembangunan berkelanjutan.

Program Adiwiyata adalah program pengelolaan lingkungan hidup di sekolah. Program ini merupakan tindak lanjut dari Kesepakatan Bersama antara Menteri Negara Lingkungan Hidup dengan Menteri Pendidikan Nasional Nomor Kep.07/MENLH/06/2005 dan Nomor
05/VI/KB/2005 tentang Pembinaan dan Pengembangan Lingkungan Hidup. Adiwiyata mempunyai pengertian atau makna: tempat yang baik dan ideal tempat diperolehnya segala ilmu pengetahuan dan berbagai norma serta etika yang dapat menjadi dasar manusia menuju terciptanya kesejahteraan hidup dan menuju kepada cita-cita pembangunan berkelanjutan. Sekolah adiwiyata adalah salah satu program Kementerian Lingkungan Hidup dalam rangka mendorong terciptanya pengetahuan dan kesadaran warga sekolah dalam upaya pelestarian lingkungan hidup. Atau Sekolah Adiwiyata adalah sekolah yang mempunyai lingkungan hidup dan melakukan pengelolaan lingkungan hidup di sekolah itu sendiri.

Pelaksanaan Program Adiwiyata diletakkan pada dua prinsip dasar berikut: (1). Partisipatif: Komunitas sekolah terlibat dalam manajemen sekolah yang meliputi keseluruhan proses perencanaan, pelaksanaan dan evaluasi sesuai tanggungjawab dan peran. (2). Berkelanjutan: Seluruh kegiatan harus dilakukan secara terencana dan terus menerus secara komprehensif.

Untuk mencapai tujuan program Adiwiyata, maka ditetapkan 4 (empat) komponen program yang menjadi satu kesatuan utuh dalam mencapai sekolah Adiwiyata. Keempat komponen tersebut adalah (1). Kebijakan Berwawasan Lingkungan. (2). Pelaksanaan Kurikulum Berbasis Lingkungan. (3). Kegiatan Lingkungan Berbasis Partisipatif. (4). Pengelolaan Sarana Pendukung Ramah Lingkungan. 
Keuntungan Mengikuti Program Adiwiyata adalah (1). Mendukung pencapaian standar kompetensi/ kompertensi dasar dan standar kompetensi lulusan (SKL) pendidikan dasar dan menengah. (2). Meningkatkan efesiensi penggunaan dana operasional sekolah melalui penghematan dan pengurangan konsumsi dari berbagai sumber daya dan energi. (3). Menciptakan kebersamaan warga sekolah dan kondisi belajar mengajar yang lebih nyaman dan kondusif. (4). Menjadi tempat pembelajaran tentang nilai-nilai pemeliharaan dan pengelolaan lingkungan hidup yang baik dan benar bagi warga sekolah dan masyarakat sekitar. (5). Meningkatkan upaya perlindungan dan pengelolaan lingkungan hidup meIalui kegiatan pengendalian pencemaran, pengendalian kerusakan dan pelestarian fungsi lingkungan di sekolah.

\section{METODE PENELITIAN}

Peneltian ini menggunakan pendekatan kualitatif, yaitu prosedur penelitian dengan hasil data deskriptif. Artinya penelitian yang menggambarkan suatu peristiwa atau kejadian yang terjadi di lapangan sebagaimana adanya tentang manajemen Kepala Sekolah dalam mewujudkan sekolah adiwiyata di SD Negeri 02 Tanah Pak Lambik Kota Padang Panjang. Metode kualitatif merupakan perosedur penelitian dengan hasil data deskriptif baik dalam bentuk kata-kata tertulis, kata-kata lisan seseorang atau perilaku manusia yang dapat diamati.

Karakteristik sumber data pada penelitian ini adalah dilihat dari keutamaan objek untuk memperoleh informasi yang lebih objektif. Sumber data dibagi kepada dua bagian, yaitu sumber data primer, yaitu Kepala sekolah pada sekolah tersebut. Sumber data sekunder adalah sebagai data pendukung yang terkait dengan penelitian ini, yaitu para guru, tenaga administrasi (TU), komite sekolah siswa dan wali murid.

Untuk menggali informasi dan mendapatkan data mengenai kepala sekolah dari sumber data yaitu guru, tenaga administrasi (TU), siswa dan wali murid, maka digunakan teknik snow ball sampling di mana sumber data dapat bertambah sesuai kebutuhan sampai diperoleh data yang valid. Hal ini sejalan dengan pendapat Lexy J. Moleong yang dikutib oleh Ridwan mengatakan bahwa jumlah informan boleh bertambah bergantung sesuai dengan keperluan peneliti berdasarkan teknik snow ballsampling (bola salju). (Ridwan: 2004: 5).

Dalam penelitian kualitatif, instrumen utama penelitian adalah peneliti. Artinya, peneliti dalam data lebih banyak bergantung kepada diri sendiri. Dengan kata lain, peneliti adalah instrumen utama penelitian. Instrumen-instrumen lainnya dapat digunakan sebagai perluasan (extension) dari si peneliti. Untuk menunjang instrument tersebut peneliti juga menggunakan instrument pendukung untuk mengumpulkan data, yaitu: (1). Observasi, (2). Wawancara, (3). Studi dokumentasi.

Pengujian keabsahan data dapat dilakukan dengan cara perpanjangan pengamatan, 
peningkatan ketekunan dalam penelitian, triangulasi, diskusi dengan teman sejawat, analisis kasus negatif, dan member check.

\section{HASIL PENELITIAN}

Berdasarkan temuan yang dikemukakan, sebelumnya dapat dikemukakan beberapa hasil penelitian, yaitu:

\section{Perencanaan Kepala Sekolah dalam mewujudkan sekolah adiwiyata di SD Negeri 02 Tanah Pak Lambik Kota Padang Panjang.}

Kepala Sekolah membuat perencanaan sebagai berikut:

a. Melibatkan semua pihak untuk kesiapan adiwiyata, yaitu: bentuk perencanaan yang telah di musyawarahkan dengan berbagai macam unsur atau elemen dari pemerintahan samapai ke tingkat komite sekolah.

b. Pembentukan tim adiwiyata dengan cara semua elemen sekolah dari guru, tenaga administratif sampai kesiswa juga dilibatkan dalam meujudkan SD Negeri 02 Tanah Pak Lambik Kota Padang Panjang menjadi sekolah adiwiyata tingkat nasional.

c. Membuat jadwal program pembinaan dari Dinas Lingkungan Hidup, dengan cara menjalin hubungan dengan dinas pendidikan dan dinas lingkungan hidup, sehingga mereka menyatakan siap untuk membina SD Negeri 02 Tanah Pak Lambik
Kota Padang Panjang menjadi sekolah adiwiyata nasional.

d. Merancang program sekolah adiwiyata, dengan carasekolah merancang semua program yang berhubungan dengan adiwiyata sekolah, yaitu program penanggulangan sampah, keanekaragaman hayati, makanan dilingkungan sekolah, penanggulangan air, dan program penghijauan ruang terbuka.

e. Mensosialisasi program adiwiyata di lingkungan sekolah dan lingkungan masyarakat, yaitu tim adiwiyata SD Negeri 02 Tanah Pak Lambik Kota Padang Panjang yang diangkat oleh kepala SD Negeri 02 Tanah Pak Lambik Kota Padang Panjang hampir setiap hari mensosialisasi program aidiyata, mulai dari apa itu adiwiyata, urgensi sekolah adiwiyata sampai mempropaganda masyarakat sekolah dan di luar sekolah untuk bekerja sama dalam mewujudkan SD Negeri 02 Tanah Pak Lambik Kota Padang Panjang menjadi sekolah adiwiyata tingkat nasional.

2. Pengorganisasian Kepala Sekolah dalam Mewujudkan Sekolah Adiwiyata di SD Negeri 02 Tanah Pak Lambik Kota Padang Panjang.

Kepala SD Negeri 02 Tanah Pak Lambik Kota Padang Panjang sebagai penanggung jawab penuh terhadap program adiyita sekolah SD Negeri 
02 Tanah Pak Lambik Kota Padang Panjang sangat selektif memilih para guru untuk mengangkat sebagai ketua tim adiwiyata sekolah.ketua tim kemudian saya bermusyawarah dengan beberapa guru lainnya untuk membantu dan bekerja sama dengan saya. Kami juga melibatkan seluruh komite sekolah, guru, tenaga administratif dan siswa dalam mewujudkan SD Negeri 02 Tanah Pak Lambik Kota Padang Panjang menjadi sekolah adiwiyata tingkat nasional dan Kepala sekolah selaku penanggung jawab penuh pada program adiwiyata sekolah melaksakan tugas dengan baik. Kepala sekolah melaksakan tugas di bantu oleh para komite sekolah, guru, tenaga administrasi dan para siswa. Dalam melaksakan tugasnya, masing-masing elemen mendapat tugas sesuai dengan bidang dan tempatnya masing-masing.

\section{PelaksanaanKepala Sekolah dalam} Mewujudkan Sekolah Adiwiyata di SD Negeri 02 Tanah Pak Lambik Kota Padang Panjang

Kepala sekolah selaku penanggung jawab penuh pada program adiwiyata sekolah melaksakan tugas dengan baik. Kepala sekolah melaksakan tugas di bantu oleh para komite sekolah, guru, tenaga administrasi dan para siswa. dalam melaksakan tugasnya, masing-masing elemen mendapat tugas sesuai dengan bidang dan tempatnya masing-masing. program pelaksanaan adiwiyata meliputi program penanggulangan sampah seperti Setiap siswa diberi satu lembar kresek. Sampah dihasilkan secara pribadi langsung masuk ke kresek itu. Setiap hari, baik dari kelas, kantin sekolah termasuk dari alam (daun-daun dan ranting pohon yang sudah tua), di pilah, organik dan non organic, program keanekaragaman hayati seperti sekolah menyediakan areal yang memfasilitasi berkembangnya keanekaragaman hayati. Salah satu nya ada kolam sederhana untuk memelihara ikan air kolam pun dapat dipakai untuk menyiram tanaman yang ada di sekitar sekolah.Juga menciptakan lingkungan yang bersih dan sehat, program makanan di lingkungan sekolah seperti Makanan yang dijual diseleksi oleh pengelola kantin, apabila tidak memenuhi syarat aman makanan tersebut tidak dapat dijaual di kantin sekolah,sekali 4 bulan Dinas Tanaman pangan turun memeriksa pasokan makanan yang di pasaok oleh wali murid atau warga tetangga di lingkungan sekolah ini, minimal sekali setahun Balai POM Padang Turun memonitor ke SD Negeri 02 Tanah Pak Lambik Kota Padang Panjang, program penanggulangan air dan program penghijauan ruang terbuka seperti usaha ekolah untuk memiliki data penggunaan air. Data itu terdiri dari bukti pembayaran pada PDAM Air yang dimanfaatkan untuk memenuhi keperluan sekolah berasal dari PDAM Kota Padang panjang. Sehingga setiap bulannya dapat dikontrol pemakain air 
dengan melihat angka dimeteran yang berjalan sesuai dengan pemakaian kita, serta dapat di lihat rekeningnya tiap bulan. Ditambah dengan program Program Penghijauan Ruang Terbuka, seperti SD Negeri 02 Tanah Pak Lambik mempunyai program untuk penghijauan ruang terbuka yaitu dengan cara penanaman pohon, lomba kebersihan taman kelas, sumbangan bunga untuk sekolah, yang dikordinir oleh kepala sekolah/komite sekolah guru kelas/siswa setiap kelas komite lingkungan/sekelompok siswa.

\section{PengontrolanKepala Sekolah dalam} Mewujudkan Sekolah Adiwiyata di SD Negeri 02 Tanah Pak Lambik Kota Padang Panjang

Dalam mewujudkan sekolah adiwiyata ini, pengontrolan dapat dilakukan oleh beberapa pihak terkait, seperti dari unsur dinas pendidikan dan lingkungan hidup Kota Padang Panjang, Kepala Sekolah, Komite Sekolah, para guru dan para siswa. Termasuk juga pada pengontrolan langsung mengenai program khusus sebagai mana yang telah dijadwalkan.

\section{PENUTUP}

\section{Kesimpulan}

Perencanaan Kepala Sekolah dalam mewujudkan sekolah adiwiyata di SD Negeri 02 Tanah Pak Lambik Kota Padang Panjang, yaitu Kepala Sekolah membuat perencanaan sebagai berikut, melibatkan semua pihak untuk kesiapan adiwiyata, pembentukan tim adiwiyata, membuat jadwal program pembinaan dari dinas lingkungan hidup, merancang program sekolah adiwiyata dan mensosialisasi program adiwiyata di lingkungan sekolah dan lingkungan masyarakat. Pengorganisasian Kepala Sekolah dalam Mewujudkan Sekolah Adiwiyata di SD Negeri 02 Tanah Pak Lambik Kota Padang Panjang yaitu Kepala SD Negeri 02 Tanah Pak Lambik Kota Padang Panjang sebagai penanggung jawab penuh terhadap program adiyita sekolah SD Negeri 02 Tanah Pak Lambik Kota Padang Panjang sangat selektif memilih para guru untuk mengangkat sebagai ketua tim adiwiyata sekolah.

PelaksanaanKepalaSekolah dalam Mewujudkan Sekolah Adiwiyata di SD Negeri 02 Tanah Pak Lambik Kota Padang Panjangyaitu Kepala sekolah selaku penanggung jawab penuh pada program adiwiyata sekolah melaksakan tugas dengan baik. Kepala sekolah melaksakan tugas di bantu oleh para komite sekolah, guru, tenaga administrasi dan para siswa. Dalam melaksakan tugasnya, masingmasing elemen mendapat tugas sesuai dengan bidang dan tempatnya masingmasing. Program pelaksanaan adiwiyata meliputi program penanggulangan sampah, program keanekaragaman hayati, program makanan di lingkungan sekolah, program penanggulangan air dan program penghijauan ruang terbuka. Pengontrolan Kepala Sekolah dalam Mewujudkan Sekolah 
Adiwiyata di SD Negeri 02 Tanah Pak Lambik Kota Padang Panjang. Dalam mewujudkan sekolah adiwiyata ini, pengontrolan dapat dilakukan oleh beberapa pihak terkait, seperti dari unsur dinas pendidikan dan lingkungan hidup Kota Padang Panjang, Kepala Sekolah, Komite Sekolah, para guru dan para siswa. Termasuk juga pada pengontrolan langsung mengenai program khusus.

\section{Saran}

a. Diharapkan kepada Dinas yang terkait agar secara kontiniutas mengontrol perkembangan sekolah yang mendapat sertifikat adiwiyata serta memberi pembinaan kepada sekolah yang belum mendapat sekolah adiwiyata.

b. Diharapkan kepada komite sekolah dan tokoh-tokoh masyarakat selalu melibatkan diri dalam memberikan masukan-masukan pada perkembagan sekolah yang telah mendapat sertifikat sekolah adiwiyata.

c. Diharapkan kepada pihak SD Negeri 02 Tanah Pak Lambik Kota Padang Panjang agar selalu membangun komunikasi demi menjaga nama baik sekolah yang telah mendapat sertifikat sekolah adiwiyata.

\section{KEPUSTAKAAN ACUAN}

Fattah Nanang, 1996, Landasan Manajemen Pendidikan, Bandung: PT Remaja Rosda Karya.

Hasibuan Malayu S.P, 1990. Manajemen Dasar, Pengetian, dan Masalah, Jakarta: CV. Haji Mas Agung.

Pidarta Made, 1988. Manajemen Pendidikan Indonesia, Jakarta: PT. Bina Aksara.

Ridwan, 2004. Metode dan Teknik Menyusun Tesis, Bandung: Al-Fabeta.

SoetopoHendityat dan SoemantoWasty, 1988, Kepemimpinan dan Supervisi Pendidikan, Jakarta: Bina Aksara.

Undang-Undang Republik Indonesia Nomor 32 Tahun 2009 Tentang Perlindungan dan Pengelolaan Lingkungan Hidup.

UsmanHusaini, 2006. Manajemen Teori, Praktik, Dan Riset Pendidikan, Jakarta: Bumi Aksara.

UU Sisdiknas No. 20 Tahun 2003.

Wahjosumidjo, 1999. Kepemimpinan Kepala Madrasah Tinjauan Teoritik dan Permasalahan, Jakarta: Raja Grafindo Persada. 